NBER WORKING PAPER SERIES

\title{
WHY DO SOME COUNTRIES PRODUCE SO MUCH MORE OUTPUT PER WORKER THAN OTHERS?
}

Robert E. Hall

Charles I. Jones

Working Paper 6564

http://www.nber.org/papers/w6564

\author{
NATIONAL BUREAU OF ECONOMIC RESEARCH \\ 1050 Massachusetts Avenue \\ Cambridge, MA 02138 \\ May 1998
}

A previous version of this paper was circulated under the title, "The Productivity of Nations." This research was supported by the Center for Economic Policy Research at Stanford and by the National Science Foundation under grants SBR-9410039 (Hall) and SBR-9510916 (Jones). We thank Bobby Sinclair for excellent research assistance and colleagues too numerous to list for an outpouring of helpful commentary. Data used in the paper are available online from http://www.stanford.edu/ chadj. Any opinions expressed are those of the authors and not those of the National Bureau of Economic Research.

(C) 1998 by Robert E. Hall and Charles I. Jones. All rights reserved. Short sections of text, not to exceed two paragraphs, may be quoted without explicit permission provided that full credit, including (C) notice, is given to the source. 
Why Do Some Countries Produce So Much

More Output per Worker than Others?

Robert E. Hall and Charles I. Jones

NBER Working Paper No. 6564

May 1998

JEL Nos. E23, O47

\begin{abstract}
Output per worker varies enormously across countries. Why? On an accounting basis, our analysis shows that differences in physical capital and educational attainment can only partially explain the variation in output per worker - we find a large amount of variation in the level of the Solow residual across countries. At a deeper level, we document that the differences in capital accumulation, productivity, and therefore output per worker are driven by differences in institutions and government policies, which we call social infrastructure. We treat social infrastructure as endogenous, determined historically by location and other factors captured in part by language.
\end{abstract}

Robert E. Hall

Hoover Institution

Stanford University

Stanford, CA 94305

and NBER

Hall@Hoover.Stanford.edu
Charles I. Jones

Department of Economics

Stanford University

Stanford, CA 94305

Chad.Jones@Stanford.edu 


\section{Introduction}

In 1988, output per worker in the United States was more than 35 times higher than output per worker in Niger. In just over ten days, the average worker in the United States produced as much as an average worker in Niger produced in an entire year. Explaining such vast differences in economic performance is one of the fundamental challenges of economics.

Analysis based on an aggregate production function provides some insight into these differences, an approach taken by Mankiw, Romer and Weil (1992) and Dougherty and Jorgenson (1996), among others. Differences among countries can be attributed to differences in human capital, physical capital, and productivity. Building on their analysis, our results suggest that differences in each element of the production function are important. In particular, however, our results emphasize the key role played by productivity. For example, consider the 35-fold difference in output per worker between the United States and Niger. Different capital intensities in the two countries contributed a factor of 1.5 to the income differences, while different levels of educational attainment contributed a factor of 3.1. The remaining difference - a factor of 7.7 - remains as the productivity residual.

The breakdown suggested by the aggregate production function is just the first step in understanding differences in output per worker. Findings in the production function framework raise deeper questions such as: Why do some countries invest more than others in physical and human capital? And why are some countries so much more productive than others? These are the questions that this paper tackles. When aggregated through the production function, the answers to these questions add up to explain the differences in output per worker across countries.

Our hypothesis is that differences in capital accumulation, productivity, and therefore output per worker are fundamentally related to differences in social infrastructure across countries. By social infrastructure, we mean 
the institutions and government policies that determine the economic environment within which individuals accumulate skills, and firms accumulate capital and produce output. A social infrastructure favorable to high levels of output per worker provides an environment that supports productive activities and encourages capital accumulation, skill acquisition, invention, and technology transfer. Such a social infrastructure gets the prices right so that, in the language of North and Thomas (1973), individuals capture the social returns to their actions as private returns.

Social institutions to protect the output of individual productive units from diversion are an essential component of a social infrastructure favorable to high levels of output per worker. Thievery, squatting, and Mafia protection are examples of diversion undertaken by private agents. Paradoxically, while the government is potentially the most efficient provider of social infrastructure that protects against diversion, it is also in practice a primary agent of diversion throughout the world. Expropriation, confiscatory taxation, and corruption are examples of public diversion. Regulations and laws may protect against diversion, but they all too often constitute the chief vehicle of diversion in an economy.

Across 127 countries, we find a powerful and close association between output per worker and measures of social infrastructure. Countries with long-standing policies favorable to productive activities - rather than diversion - produce much more output per worker. For example, our analysis suggests that the observed difference in social infrastructure between Niger and the United States is more than enough to explain the 35-fold difference in output per worker.

Our research is related to many earlier contributions. The large body of theoretical and qualitative analysis of property rights, corruption, and economic success will be discussed in Section 3. The recent empirical growth literature associated with Barro (1991) and others shares some common 
elements with our work, but our empirical framework differs fundamentally in its focus on levels instead of rates of growth. This focus is important for several reasons.

First, levels capture the differences in long-run economic performance that are most directly relevant to welfare as measured by the consumption of goods and services.

Second, several recent contributions to the growth literature point toward a focus on levels instead of growth rates. Easterly, Kremer, Pritchett and Summers (1993) document the relatively low correlation of growth rates across decades, which suggests that differences in growth rates across countries may be mostly transitory. Jones (1995) questions the empirical relevance of endogenous growth and presents a model in which different government policies are associated with differences in levels, not growth rates. Finally, a number of recent models of idea flows across countries such as Parente and Prescott (1994), Barro and Sala-i-Martin (1995) and Eaton and Kortum (1995) imply that all countries will grow at a common rate in the long run: technology transfer keeps countries from drifting indefinitely far from each other. In these models, long-run differences in levels are the interesting differences to explain.

Some of the cross-country growth literature recognizes this point. In particular, the growth regressions in Mankiw et al. (1992) and Barro and Salai-Martin (1992) are explicitly motivated by a neoclassical growth model in which long-run growth rates are the same across countries or regions. These studies emphasize that differences in growth rates are transitory: countries grow more rapidly the further they are below their steady state. Nevertheless, the focus of such growth regressions is to explain the transitory differences in growth rates across countries. ${ }^{1}$ Our approach is different-we

\footnotetext{
${ }^{1}$ The trend in the growth literature has been to use more and more of the short-run variation in the data. For example, several recent studies use panel data at 5 or 10 -year intervals and include country fixed effects. The variables we focus on change so slowly
} 
try to explain the variation in long-run economic performance by studying directly the cross-section relation in levels. ${ }^{2}$

The purpose of this paper is to call attention to the strong relation between social infrastructure and output per worker. Countries with corrupt government officials, severe impediments to trade, poor contract enforcement, and government interference in production will be unable to achieve levels of output per worker anywhere near the norms of western Europe, northern America, and eastern Asia. Our contribution is to show, quantitatively, how important these effects are.

We can summarize our analysis of the determinants of differences in economic performance among countries as:

\section{Output per Worker $\longleftarrow$ (Inputs, Productivity) $\longleftarrow$ Social Infrastructure.}

This framework serves several purposes. First, it allows us to distinguish between the proximate causes of economic success - capital accumulation and productivity - and the more fundamental determinant. Second, the framework clarifies the contribution of our work. We concentrate on the relation between social infrastructure and differences in economic performance. The production function-productivity analysis allows us to trace this relation through capital accumulation and productivity.

We are conscious that feedback may occur from output per worker back to social infrastructure. For example, it may be that poor countries lack the resources to build effective social infrastructures. We control for this feedback by using the geographical and linguistic characteristics of an economy as instrumental variables. We view these characteristics as measures of over time that their effects may be missed entirely in such studies.

${ }^{2}$ Chari, Kehoe and McGrattan (1997) also analyze levels of economic performance. In cross-country growth regressions that include the initial level of income and emphasize the transition dynamics interpretation, one can map the growth regression coefficients into effects on the long-run level of income. However, we know of only one attempt to do this mapping, the prepublication version of Sachs and Warner (1997). 
the extent to which an economy is influenced by Western Europe, the first region of the world to implement broadly a social infrastructure favorable to production. Controlling for endogeneity, we still find that differences in social infrastructure across countries account for much of the difference in long-run economic performance around the world.

\section{Levels Accounting}

Our analysis begins by examining the proximate causes of economic success. We decompose differences in output per worker across countries into differences in inputs and differences in productivity.

There are three approaches to the decomposition of output per worker into inputs and productivity. One was developed by Christensen, Cummings and Jorgenson (1981) and involves the comparison of each country to a reference point. A country's productivity residual is formed by weighting the log-differences of each factor input from the reference point by the arithmetic average of the country's factor share and the reference factor share. The second is similar, except that the factor shares are assumed to be the same for all countries; this amounts to calculating the residual from a CobbDouglas technology. Finally, there is a method based directly on Solow (1957), discussed in a predecessor to this paper, Hall and Jones (1996), and summarized below. Because the Solow method gives results quite similar to those based on Christensen et al. (1981) or on Cobb-Douglas with standard elasticities, we will not dwell on this aspect of the work. We present results based on the simplest Cobb-Douglas approach.

Assume output $Y_{i}$ in country $i$ is produced according to

$$
Y_{i}=K_{i}^{\alpha}\left(A_{i} H_{i}\right)^{1-\alpha}
$$

where $K_{i}$ denotes the stock of physical capital, $H_{i}$ is the amount of human capital-augmented labor used in production, and $A_{i}$ is a labor-augmenting 
measure of productivity. We assume labor $L_{i}$ is homogeneous within a country and that each unit of labor has been trained with $E_{i}$ years of schooling (education). Human capital-augmented labor is given by

$$
H_{i}=e^{\phi\left(E_{i}\right)} L_{i}
$$

In this specification, the function $\phi(E)$ reflects the efficiency of a unit of labor with $E$ years of schooling relative to one with no schooling $(\phi(0)=0)$. The derivative $\phi^{\prime}(E)$ is the return to schooling estimated in a Mincerian wage regression (Mincer 1974): an additional year of schooling raises a worker's efficiency proportionally by $\phi^{\prime}(E){ }^{3}$ Note that if $\phi(E)=0$ for all $E$ this is a standard production function with undifferentiated labor.

With data on output, capital, and schooling, and knowledge of $\alpha$ and $\phi(\cdot)$, one can calculate the level of productivity directly from the production function. It turns out to be convenient to rewrite the production function in terms of output per worker, $y \equiv Y / L$, as

$$
y_{i}=\left(\frac{K_{i}}{Y_{i}}\right)^{\alpha /(1-\alpha)} h_{i} A_{i},
$$

where $h \equiv H / L$ is human capital per worker.

This equation allows us to decompose differences in output per worker across countries into differences in the capital-output ratio, differences in educational attainment, and differences in productivity. We follow David (1977), Mankiw et al. (1992) and Klenow and Rodriguez-Clare (1997) in writing the decomposition in terms of the capital-output ratio rather than the capital-labor ratio, for two reasons. First, along a balanced growth path, the capital-output ratio is proportional to the investment rate, so that this form of the decomposition also has a natural interpretation. Second, consider a country that experiences an exogenous increase in productivity,

\footnotetext{
${ }^{3}$ Bils and Klenow (1996) suggest that this is the appropriate way to incorporate years of schooling into an aggregate production function.
} 
holding its investment rate constant. Over time, the country's capital-labor ratio will rise as a result of the increase in productivity. Therefore, some of the increase in output that is fundamentally due to the increase in productivity would be attributed to capital accumulation in a framework based on the capital-labor ratio.

To measure productivity and decompose differences in output per worker into differences in capital intensity, human capital per worker, and productivity, we use data on output, labor input, average educational attainment, and physical capital for the year 1988.

Our basic measure of economic performance is the level of output per worker. National income and product account data and labor force data are taken from the Penn World Tables Mark 5.6 revision of Summers and Heston (1991). We do not have data on hours per worker for most countries, so we use the number of workers instead of hours to measure labor input. Our calculations of productivity also incorporate a correction for natural resources used as inputs. Because of inadequate data, our correction is quite coarse: we subtract value added in the mining industry (which includes oil and gas) from GDP in computing our measure of output. That is, we assign all of mining value added to natural resource inputs and neglect capital and labor inputs in mining. Without this correction, resource-rich countries such as Oman and Saudi Arabia would be among the top countries in terms of productivity. ${ }^{4}$ Average educational attainment is measured in 1985 for the population aged 25 and over, as reported by Barro and Lee (1993). Physical capital stocks are constructed using the perpetual inventory method. ${ }^{5}$

\footnotetext{
${ }^{4}$ Apart from the ranking of productivity and output per worker, none of our empirical results that follow are sensitive to this correction. We compute the mining share of GDP in current prices from United Nations (1994) for most countries. Data for China, Israel, Czechoslovakia, Ireland, Italy, Poland, and Romania are taken from United Nations (1993).

${ }^{5}$ We limit our sample to countries with investment data going back at least to 1970 and use all available investment data. For example, suppose 1960 is the first year of investment data for some country. We estimate the initial value of the 1960 capital stock for that country as $I_{60} /(g+\delta)$ where $g$ is calculated as the average geometric growth rate from
} 
Because we only need data on the capital stock for 1988, our measure is quite insensitive to the choice of the initial value. Our data set includes 127 countries. $^{6}$

Regarding the parameters of the production function, we take a standard neoclassical approach. ${ }^{7}$ We assume a value of $\alpha=1 / 3$, which is broadly consistent with national income accounts data for developed countries. With respect to human capital, Psacharopoulos (1994) surveys evidence from many countries on return-to-schooling estimates. Based on his summary of Mincerian wage regressions, we assume that $\phi(E)$ is piecewise linear. Specifically, for the first 4 years of education, we assume a rate of return of 13.4 percent, corresponding to the average Psacharopoulos reports for sub-Saharan Africa. For the next 4 years, we assume a value of 10.1 percent, the average for the world as a whole. Finally, for education beyond the 8th year, we use the value Psacharopoulos reports for the OECD, 6.8 percent.

\subsection{Productivity Calculations by Country}

Figure 1 shows productivity levels across countries plotted against output per worker. The figure illustrates that differences in productivity are very similar to differences in output per worker; the correlation between the two series (in logs) is 0.89. Apart from Puerto Rico ${ }^{8}$, the countries with the

1960 to 1970 of the investment series. We assume a depreciation rate of 6 percent.

${ }^{6}$ As discussed in more detail later, we had to impute the data on educational attainment for 27 of these countries.

${ }^{7}$ This is a natural benchmark. It ignores externalities from physical and human capital. We believe there is little compelling evidence of such externalities, much less any estimate of their magnitudes. We leave a more general analysis of such possibilities in our framework to future work.

${ }^{8}$ Puerto Rico deserves special mention as it is - by far - the most productive country according to our calculation. Its output per worker is similar to that in the U.K. but measured inputs are much lower. The result is a high level of productivity. Baumol and Wolff (1996) comment on Puerto Rico's extraordinary recent growth in output per worker. In addition, there is good reason to believe that Puerto Rico's national income accounts overstate output. Many U.S. firms have located production facilities there because of low tax rates. To take maximum advantage of those low rates and to avoid higher U.S. rates, 
Figure 1: Productivity and Output per Worker

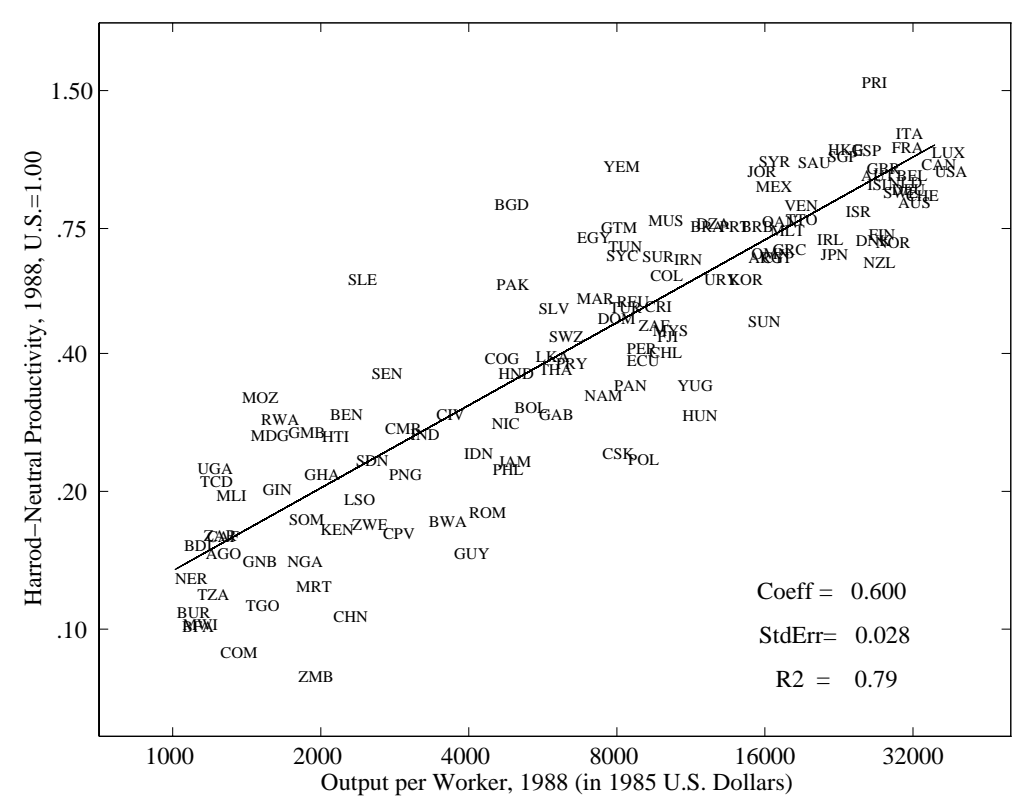

highest levels of productivity are Italy, France, Hong Kong, Spain, and Luxembourg. Those with the lowest levels are Zambia, Comoros, Burkina Faso, Malawi, and China. U.S. productivity ranks 13th out of 127 countries.

Table 1 decomposes output per worker in each country into the three multiplicative terms in equation (3): the contribution from physical capital intensity, the contribution from human capital per worker, and the contribution from productivity. It is important to note that this productivity level is calculated as a residual, just as in the growth accounting literature.

To make the comparisons easier, all terms are expressed as ratios to U.S. values. ${ }^{9}$ For example, according to this table, output per worker in Canada

they may report exaggerated internal transfer prices when the products are moved within the firm from Puerto Rico back to the U.S. When these exaggerated non-market prices are used in the Puerto Rican output calculations, they result in an overstatement of real output.

${ }^{9} \mathrm{~A}$ complete set of results is reported in the Appendix table. 
Table 1: Productivity Calculations: Ratios to U.S. Values

\begin{tabular}{|c|c|c|c|c|}
\hline \multirow[b]{2}{*}{ Country } & \multirow[b]{2}{*}{$Y / L$} & \multicolumn{3}{|c|}{ 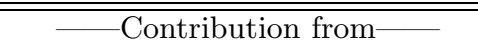 } \\
\hline & & $(K / Y)^{\alpha /(1-\alpha)}$ & $H / L$ & $A$ \\
\hline United States & 1.000 & 1.000 & 1.000 & 1.000 \\
\hline Canada & 0.941 & 1.002 & 0.908 & 1.034 \\
\hline Italy & 0.834 & 1.063 & 0.650 & 1.207 \\
\hline West Germany & 0.818 & 1.118 & 0.802 & 0.912 \\
\hline France & 0.818 & 1.091 & 0.666 & 1.126 \\
\hline United Kingdom & 0.727 & 0.891 & 0.808 & 1.011 \\
\hline Hong Kong & 0.608 & 0.741 & 0.735 & 1.115 \\
\hline Singapore & 0.606 & 1.031 & 0.545 & 1.078 \\
\hline Japan & 0.587 & 1.119 & 0.797 & 0.658 \\
\hline Mexico & 0.433 & 0.868 & 0.538 & 0.926 \\
\hline Argentina & 0.418 & 0.953 & 0.676 & 0.648 \\
\hline U.S.S.R. & 0.417 & 1.231 & 0.724 & 0.468 \\
\hline India & 0.086 & 0.709 & 0.454 & 0.267 \\
\hline China & 0.060 & 0.891 & 0.632 & 0.106 \\
\hline Kenya & 0.056 & 0.747 & 0.457 & 0.165 \\
\hline Zaire & 0.033 & 0.499 & 0.408 & 0.160 \\
\hline Average, 127 Countries: & 0.296 & 0.853 & 0.565 & 0.516 \\
\hline Standard Deviation: & 0.268 & 0.234 & 0.168 & 0.325 \\
\hline Correlation w/ $Y / L(\operatorname{logs})$ & 1.000 & 0.624 & 0.798 & 0.889 \\
\hline Correlation w/ $A(\operatorname{logs})$ & 0.889 & 0.248 & 0.522 & 1.000 \\
\hline $\begin{array}{l}\text { Note: The elements of this } \\
\text { components of equation }(3 \\
\text { ues. That is, the first colun } \\
\text { columns. }\end{array}$ & $\begin{array}{l}\text { able } \\
\text { all } \\
\text { of } \mathrm{c}\end{array}$ & $\begin{array}{l}\text { he empirical } \\
\text { sured as rat } \\
\text { is the produ }\end{array}$ & $\begin{array}{l}\text { unter } \\
\text { to tl } \\
\text { f the }\end{array}$ & $\begin{array}{l}\text { S to the } \\
\text { J.S. val } \\
\text { er three }\end{array}$ \\
\hline
\end{tabular}

is about 94 percent of that in the United States. Canada has about the same capital intensity as the United States, but only 91 percent of U.S. human capital per worker. Differences in inputs explain lower Canadian output per worker, so Canadian productivity is about the same as U.S. productivity. Other OECD economies such as the United Kingdom also have productivity levels close to U.S. productivity. Italy and France are 
slightly higher; Germany is slightly lower. ${ }^{10}$

Consistent with conventional wisdom, the U.S.S.R. has extremely high capital intensity and relatively high human capital but a rather low productivity level. For the developing countries in the table, differences in productivity are the most important factor in explaining differences in output per worker. For example, Chinese output per worker is about 6 percent of that in the United States, and the bulk of this difference is due to lower productivity: without the difference in productivity, Chinese output per worker would be more than 50 percent of U.S. output per worker.

The bottom half of Table 1 reports the average and standard deviation of the contribution of inputs and productivity to differences in output per worker. According to either statistic, differences in productivity across countries are substantial. A simple calculation emphasizes this point. Output per worker in the five countries in 1988 with the highest levels of output per worker was 31.7 times higher than output per worker in the five lowest countries (based on a geometric average). Relatively little of this difference was due to physical and human capital: differences in capital intensity and human capital per worker contributed factors of 1.8 and 2.2, respectively, to the difference in output per worker. Productivity, however, contributed a factor of 8.3 to this difference: with no differences in productivity, output per worker in the five richest countries would have been only about four times larger than in the five poorest countries. In this sense, differences in physical capital and educational attainment explain only a modest amount of the difference in output per worker across countries.

The reason for the lesser importance of capital accumulation is that most of the variation in capital-output ratios arises from variation in investment rates. Average investment rates in the five richest countries are only 2.9 times larger than average investment rates in the five poorest countries.

\footnotetext{
${ }^{10}$ Hours per worker are higher in the United States than in France and Italy, making their productivity levels more surprising.
} 
Moreover, this difference gets raised to the power $\alpha /(1-\alpha)$ which for a neoclassical production function with $\alpha=1 / 3$ is only $1 / 2$ - so it is the square root of the difference in investment rates that matters for output per worker. Similarly, average educational attainment in the five richest countries is about 8.1 years greater than average educational attainment in the five poorest countries, and this difference also gets reduced when converted into an effect on output: each year of schooling contributes only something like 10 percent (the Mincerian return to schooling) to differences in output per worker. Given the relatively small variation in inputs across countries and the small elasticities implied by neoclassical assumptions, it is hard to escape the conclusion that differences in productivity - the residual - play a key role in generating the wide variation in output per worker across countries.

Our earlier paper, Hall and Jones (1996), compared results based on the Cobb-Douglas formulation with alternative results based on the application of Solow's method with a spatial rather than temporal ordering of observations. ${ }^{11}$ In this latter approach, the production function is not restricted to Cobb-Douglas and factor shares are allowed to differ across countries. The results were very similar. We do not think that the simple Cobb-Douglas approach introduces any important biases into any of the results presented in this paper.

Our calculation of productivity across countries is related to a calculation performed by Mankiw et al. (1992). Two important differences are

\footnotetext{
${ }^{11}$ More specifically, assume that the index for observations in a standard growth accounting framework with $Y=A F(K, H)$ refers to countries rather than time. The standard accounting formula still applies: the difference in output between two countries is equal to a weighted average of the differences in inputs plus the difference in productivity, where the weights are the factor shares. As in Solow (1957), the weights will generally vary across observations. The only subtlety in this calculation is that time has a natural order, whereas countries do not. In our calculations, we found that the productivity results were robust to different orderings (in order of output per worker or of total factor input, for example).
} 
worth noting. First, they estimate the elasticities of the production function econometrically. Their identifying assumption is that differences in productivity across countries are uncorrelated with physical and human capital accumulation. This assumption seems questionable, as countries that provide incentives for high rates of physical and human capital accumulation are likely to be those that use their inputs productively, particularly if our hypothesis that social infrastructure influences all three components has any merit. Our empirical results also call this identifying assumption into question since, as shown in Table 1, our measure of productivity is highly correlated with human capital accumulation and moderately correlated with the capital-output ratio. Second, they give little emphasis to differences in productivity, which are econometric residuals in their framework; they emphasize the explanatory power of differences in factor inputs for differences in output across countries. In contrast, we emphasize our finding of substantial differences in productivity levels across countries. Our productivity differences are larger in part because of our more standard treatment of human capital and in part because we do not impose orthogonality between productivity and the other factors of production. ${ }^{12}$

Finally, a question arises as to why we find a large Solow residual in levels. What do the measured differences in productivity across countries actually reflect? First, from an accounting standpoint, differences in physical capital intensity and differences in educational attainment explain only a small fraction of the differences in output per worker across countries. One interpretation of this result is that we must turn to other differences,

\footnotetext{
${ }^{12}$ In helping us to think about the differences, David Romer suggested that the treatment of human capital in MRW implies that human capital per worker varies by a factor of more than 1200 in their sample, which may be much higher than is reasonable. Klenow and Rodriguez-Clare (1997) explore the differences between these two approaches in more detail. Extending the MRW analysis, Islam (1995) reports large differences in productivity levels, but his results, led by econometric estimates, neglect differences in human capital in computing the levels.
} 
such as the quality of human capital, on-the-job training, or vintage effects. That is, we could add to the inputs included in the production function. A second and complementary interpretation of the result suggests that a theory of productivity differences is needed. Differences in technologies may be important — for example, Parente and Prescott (1996) construct a theory in which insiders may prevent new technologies from being adopted. In addition, in economies with social infrastructures not conducive to efficient production, some resources may be used to protect against diversion rather than to produce output: capital could consist of security systems and fences rather than factories and machinery. Accounting for the differences in productivity across countries is a promising area of future research.

\section{Determinants of Economic Performance}

At an accounting level, differences in output per worker are due to differences in physical and human capital per worker and to differences in productivity. But why do capital and productivity differ so much across countries? The central hypothesis of this paper is that the primary, fundamental determinant of a country's long-run economic performance is its social infrastructure. By social infrastructure, we mean the institutions and government policies that provide the incentives for individuals and firms in an economy. Those incentives can encourage productive activities such as the accumulation of skills or the development of new goods and production techniques, or those incentives can encourage predatory behavior such as rent-seeking, corruption, and theft.

Productive activities are vulnerable to predation. If a farm cannot be protected from theft, then thievery will be an attractive alternative to farming. A fraction of the labor force will be employed as thieves, making no contribution to output. Farmers will spend more of their time protecting their farms from thieves and consequently grow fewer crops per hour of 
effort.

Social control of diversion has two benefits. First, in a society free of diversion, productive units are rewarded by the full amount of their production - where there is diversion, on the other hand, it acts like a tax on output. Second, where social control of diversion is effective, individual units do not need to invest resources in avoiding diversion. In many cases, social control is much cheaper than private avoidance. Where there is no effective social control of burglary, for example, property owners must hire guards and put up fences. Social control of burglary involves two elements. First is the teaching that stealing is wrong. Second is the threat of punishment. The threat itself is free - the only resources required are those needed to make the threat credible. The value of social infrastructure goes far beyond the notion that collective action can take advantage of returns to scale in avoidance. It is not that the city can put up fences more cheaply than can individuals - in a city run well, no fences are needed at all.

Social action - typically through the government-is a prime determinant of output per worker in almost any view. The literature in this area is far too voluminous to summarize adequately here. Important contributions are Olson (1965), Olson (1982), Baumol (1990), North (1990), Greif and Kandel (1995), and Weingast (1995).

A number of authors have developed theoretical models of equilibrium when protection against predation is incomplete. ${ }^{13}$ Workers choose between production and diversion. There may be more than one equilibrium - for example, there may be a poor equilibrium where production pays little because diversion is so common, and diversion has a high payoff because enforcement is ineffective when diversion is common. There is also a good equilibrium with little diversion, because production has a high payoff and the high probability of punishment deters almost all diversion. Rapaczynski (1987)

\footnotetext{
${ }^{13}$ See, for example, Murphy, Shleifer and Vishny (1991), Acemoglu (1995), Schrag and Scotchmer (1993), Ljungqvist and Sargent (1995), Grossman and Kim (1996).
} 
gives Hobbes credit for originating this idea. Even if there is only a single equilibrium in these models, it may be highly sensitive to its determinants because of near-indeterminacy.

Thus the suppression of diversion is a central element of a favorable social infrastructure. The government enters the picture in two ways. First, the suppression of diversion appears to be most efficient if it is carried out collectively, so the government is the natural instrument of anti-diversion efforts. Second, the power to make and enforce rules makes the government itself a very effective agent of diversion. A government supports productive activity by deterring private diversion and by refraining from diverting itself. Of course, governments need revenue in order to carry out deterrence, which requires at least a little diversion through taxation.

Diversion takes the form of rent seeking in countries of all types, and is probably the main form of diversion in more advanced economies (Krueger 1974). Potentially productive individuals spend their efforts influencing the government. At high levels, they lobby legislatures and agencies to provide benefits to their clients. At lower levels, they spend time and resources seeking government employment. They use litigation to extract value from private business. They take advantage of ambiguities in property rights.

Successful economies limit the scope of rent seeking. Constitutional provisions restricting government intervention, such as the provisions in the U.S. Constitution prohibiting interference with interstate commerce, reduce opportunities for rent seeking. A good social infrastructure will plug as many holes as it can where otherwise people could spend time bettering themselves economically by methods other than production. In addition to its direct effects on production, a good social infrastructure may have important indirect effects by encouraging the adoption of new ideas and new technologies as they are invented throughout the world. 


\section{Estimating the Effect of Social Infrastructure}

Two important preliminary issues are the measurement of social infrastructure and the econometric identification of our model.

\subsection{Measurement}

The ideal measure of social infrastructure would quantify the wedge between the private return to productive activities and the social return to such activities. A good social infrastructure ensures that these returns are kept closely in line across the range of activities in an economy, from working in a factory to investing in physical or human capital to creating new ideas or transferring technologies from abroad, on the positive side, and from theft to corruption on the negative side.

In practice, however, there does not exist a usable quantification of wedges between private and social returns, either for single countries or for the large group of countries considered in this study. As a result, we must rely on proxies for social infrastructure and recognize the potential for measurement error.

We form our measure of social infrastructure by combining two indexes. The first is an index of government anti-diversion policies (GADP) created from data assembled by a firm that specializes in providing assessments of risk to international investors, Political Risk Services. ${ }^{14}$ Their International Country Risk Guide rates 130 countries according to 24 categories. We follow Knack and Keefer (1995) in using the average of 5 of these categories for the years 1986-1995. Two of the categories relate to the government's role in protecting against private diversion: (i) law and order, and (ii) bu-

\footnotetext{
${ }^{14}$ See Coplin, O'Leary and Sealy (1996) and Knack and Keefer (1995). Barro (1997) considers a measure from the same source in regressions with the growth of GDP per capita. Mauro (1995) uses a similar variable to examine the relation between investment and growth of income per capita, on the one hand, and measures of corruption and other failures of protection, on the other hand.
} 
reaucratic quality. Three categories relate to the government's possible role as a diverter: (i) corruption, (ii) risk of expropriation, and (iii) government repudiation of contracts. Our GADP variable is an equal-weighted average of these 5 variables, each of which has higher values for governments with more effective policies for supporting production. The index is measured on a scale from zero to one.

The second element of our measure of social infrastructure captures the extent to which a country is open to international trade. Policies toward international trade are a sensitive index of social infrastructure. Not only does the imposition of tariffs divert resources to the government, but tariffs, quotas, and other trade barriers create lucrative opportunities for private diversion. In addition, policies favoring free trade yield benefits associated with the trade itself. Trade with other countries yields benefits from specialization and facilitates the adoption of ideas and technologies from those countries. Our work does not attempt to distinguish between trade policies as measures of a country's general infrastructure and the specific benefits that come from free trade itself.

Sachs and Warner (1995) have compiled an index that focuses on the openness of a country to trade with other countries. An important advantage of their variable is that it considers the time since a country adopted a more favorable social infrastructure. The Sachs-Warner index measures the fraction of years during the period 1950 to 1994 that the economy has been open and is measured on a $[0,1]$ scale. A country is open if it satisfies all of the following criteria: (i) nontariff barriers cover less than 40 percent of trade, (ii) average tariff rates are less than 40 percent, (iii) any black market premium was less than 20 percent during the 1970s and 1980s, (iv) the country is not classified as socialist by Kornai (1992), and (v) the government does not monopolize major exports.

In most of the results that we present, we will impose (after testing) the 
restriction that the coefficients for these two proxies for social infrastructure are the same. Hence, we focus primarily on a single index of social infrastructure formed as the average of the GADP and openness measures.

\subsection{Identification}

To examine the quantitative importance of differences in social infrastructure as determinants of incomes across countries, we hypothesize the following structural model:

$$
\log Y / L=\alpha+\beta S+\epsilon,
$$

and

$$
S=\gamma+\delta \log Y / L+X \theta+\eta,
$$

where $S$ denotes social infrastructure and $X$ is a collection of other variables.

Several features of this framework deserve comment. First, we recognize explicitly that social infrastructure is an endogenous variable. Economies are not exogenously endowed with the institutions and incentives that make up their economic environments, but rather social infrastructure is determined endogenously, perhaps depending itself on the level of output per worker in an economy. Such a concern arises not only because of the general possibility of feedback from the unexplained component of output per worker to social infrastructure, but also from particular features of our measure of social infrastructure. For example, poor countries may have limited ability to collect taxes and may therefore be forced to interfere with international trade. Alternatively, one might be concerned that the experts at Political Risk Services who constructed the components of the GADP index were swayed in part by knowledge of income levels.

Second, our specification for the determination of incomes in equation (4) is parsimonious, reflecting our hypothesis that social infrastructure is the primary and fundamental determinant of output per worker. We allow for a rich determination of social infrastructure through the variables in the $X$ 
matrix. Indeed, we will not even attempt to describe all of the potential determinants of social infrastructure - we will not estimate equation (5) of the structural model. The heart of our identifying assumptions is the restriction that the determinants of social infrastructure affect output per worker only through social infrastructure and not directly. We test the exclusion below.

Our identifying scheme includes the assumption that $E X^{\prime} \epsilon=0$. Under this assumption, any subset of the determinants of social infrastructure constitute valid instruments for estimation of the parameters in equation (4). Consequently, we do not require a complete specification of that equation. We will return to this point in greater detail shortly.

Finally, we augment our specification by recognizing, as discussed in the previous section, that we do not observe social infrastructure directly. Instead, we observe a proxy variable $\tilde{S}$ computed as the sum of GADP and the openness variable, normalized to a $[0,1]$ scale. This proxy for social infrastructure is related to true social infrastructure through random measurement error:

$$
\tilde{S}=\psi S+\nu
$$

where $\nu$ is the measurement error, taken to be uncorrelated with $S$ and $X$. Without loss of generality, we normalize $\psi=1$; this is an arbitrary choice of units since $S$ is unobserved. Therefore,

$$
S=\tilde{S}-\nu
$$

Using this measurement equation, we rewrite equation (4) as

$$
\log Y / L=\alpha+\beta \tilde{S}+\tilde{\epsilon}
$$

where

$$
\tilde{\epsilon} \equiv \epsilon-\beta \nu
$$


The coefficient $\beta$ will be identified by the orthogonality conditions $E X^{\prime} \tilde{\epsilon}=$ 0 . Therefore, both measurement error and endogeneity concerns are addressed. The remaining issue to discuss is how we obtain valid instruments for GADP and our openness measure.

\subsection{Instruments}

Our choice of instruments considers several centuries of world history. One of the key features of the 16th through 19th centuries was the expansion of Western European influence around the world. The extent of this influence was far from uniform, and thus provides us with identifying variation which we will take to be exogenous. Our instruments are various correlates of the extent of Western European influence. These are characteristics of geography such as distance from the equator and the extent to which the primary languages of Western Europe - English, French, German, Portuguese, and Spanish — are spoken as first languages today.

Our instruments are positively correlated with social infrastructure. Western Europe discovered the ideas of Adam Smith, the importance of property rights, and the system of checks and balances in government, and the countries that were strongly influenced by Western Europe were, other things equal, more likely to adopt favorable infrastructure.

That the extent to which the languages of Western Europe are spoken as a mother tongue is correlated with the extent of Western European influence seems perfectly natural. However, one may wonder about the correlation of distance from the equator with Western European influence. We suggest this is plausible for two reasons. First, Western Europeans were more likely to migrate to and settle regions of the world that were sparsely populated at the start of the 15th century. Regions such as the United States, Canada, Australia, New Zealand, and Argentina appear to satisfy this criterion. Second, it appears that Western Europeans were more likely to settle in areas 
that were broadly similar in climate to Western Europe, which again points to regions far from the equator. ${ }^{15}$

The other important characteristic of an instrument is lack of correlation with the disturbance $\tilde{\epsilon}$. To satisfy this criterion, we must ask if European influence was somehow more intensively targeted toward regions of the world that are more likely to have high output per worker today. In fact, this does not seem to be the case. On the one hand, Europeans did seek to conquer and exploit areas of the world that were rich in natural resources such as gold and silver or that could provide valuable trade in commodities such as sugar and molasses. There is no tendency today for these areas to have high output per worker.

On the other hand, European influence was much stronger in areas of the world that were sparsely settled at the beginning of the 16th century, such as the United States, Canada, Australia, New Zealand, and Argentina. Presumably, these regions were sparsely settled at that time because the land was not especially productive given the technologies of the 15th century. For these reasons, it seems reasonable to assume that our measures of Western European influence are uncorrelated with $\tilde{\epsilon}$.

We measure distance from the equator as the absolute value of latitude in degrees divided by 90 to place it on a 0 to 1 scale. ${ }^{16}$ It is widely known that economies further from the equator are more successful in terms of per capita income. For example, Nordhaus (1994) and Theil and Chen (1995) examine

\footnotetext{
${ }^{15}$ Engerman and Sokoloff (1997) provide a detailed historical analysis complementary to this story. They conclude that factor endowments such as geography, climate, and soil conditions help explain why the social infrastructure that developed in the United States and Canada was more conducive to long-run economic success than the social infrastructure that developed in Latin America.

${ }^{16}$ The latitude of each country was obtained from the Global Demography Project at U.C. Santa Barbara (http://www.ciesin.org/datasets/gpw/globldem.doc.html), discussed by Tobler, Deichmann, Gottsegen and Maloy (1995). These location data correspond to the center of the county or province within a country that contains the largest number of people. One implication of this choice is that the data source places the center of the United States in Los Angeles, somewhat south of the median latitude of the country.
} 
closely the simple correlation of these variables. However, the explanation for this correlation is far from agreed upon. Kamarck (1976) emphasizes a direct relationship through the prevalence of disease and the presence of a highly variable rainfall and inferior soil quality. We will postulate that the direct effect of such factors is small and impose the hypothesis that the effect is zero - hence distance from the equator is not included in equation (4). Because of the presence of overidentifying restrictions in our framework, however, we are able to test this hypothesis, and we do not reject it, either statistically or economically, as discussed later in the paper.

Our data on languages comes from two sources: Hunter (1992), and, to a lesser extent, Gunnemark (1991). ${ }^{17}$ We use two language variables: the fraction of a country's population speaking one of the five primary Western European languages (including English) as a mother tongue, and the fraction speaking English as a mother tongue. We are, therefore, allowing English and the other languages to have separate impacts.

Finally, we also use as an instrument the variable constructed by Frankel and Romer (1996): the (log) predicted trade share of an economy, based on a gravity model of international trade that only uses a country's population and geographical features.

Our data set includes 127 countries for which we were able to construct measures of the physical capital stock using the Summers and Heston data set. For these 127 countries, we were also able to obtain data on the primary languages spoken, geographic information, and the Frankel-Romer predicted trade share. However, missing data was a problem for four variables: 16 countries in our sample were missing data on the openness variable, 17 were missing data on the GADP variable, 27 were missing data on educational attainment, and 15 were missing data on the mining share of GDP. We imputed values for these missing data using the 79 countries for which we

\footnotetext{
${ }^{17}$ The sources often disagree on exact numbers. Hunter (1992) is much more precise, containing detailed data on various dialects and citations to sources (typically surveys).
} 
Figure 2: Social Infrastructure and Output Per Worker

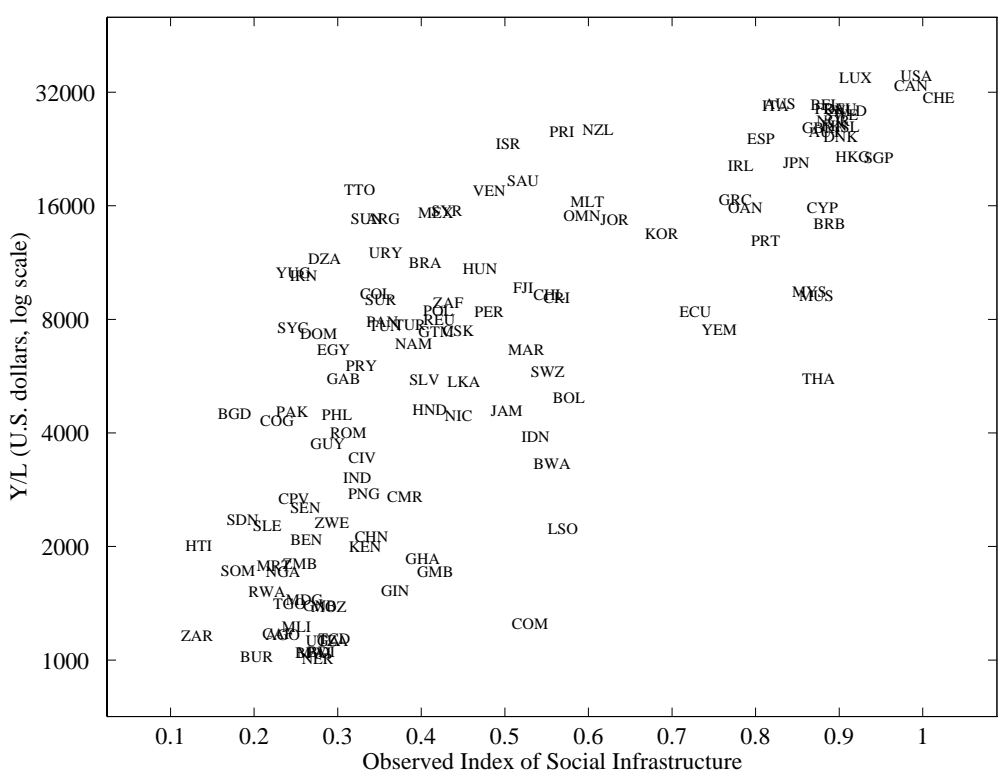

have a complete set of data. ${ }^{18}$

\section{$5 \quad$ Basic Results}

Figure 2 plots output per worker against our measured index of social infrastructure. The countries with the highest measured levels of social infrastructure are Switzerland, the United States, and Canada, and all three

\footnotetext{
${ }^{18}$ For each country with missing data, we used a set of independent variables to impute the missing data. Specifically, let $C$ denote the set of 79 countries with complete data. Then, (i) For each country $i$ not in $C$, let $W$ be the independent variables with data and $V$ be the variables that are missing data. (ii) Using the countries in $C$, regress $V$ on $W$. (iii) Use the coefficients from these regressions and the data $W(i)$ to impute the values of $V(i)$. The variables in $V$ and $W$ were indicator variables for type of economic organization, the fraction of years open, GADP, the fraction of population speaking English at home, the fraction of population speaking a European language at home, and a quadratic polynomial for distance from the equator. In addition, total educational attainment and the mining share of GDP were included in $V$ but not in $W$, i.e. they were not treated as independent.
} 
are among the countries with the highest levels of output per worker. Three countries that are close to the lowest in social infrastructure are Zaire, Haiti, and Bangladesh, and all three have low levels of output per worker.

Consideration of this figure leads to two important questions addressed in this section. First, what is the impact on output per worker of a change in an exogenous variable that leads to a one unit increase in social infrastructure? Second, what is the range of variation of true social infrastructure? We see in Figure 2 that measured social infrastructure varies considerably along this 10-point scale. How much of this is measurement error, and how much variation is there across countries in true social infrastructure? Combining the answers to these two general questions allows us to quantify the overall importance of differences in social infrastructure across countries in explaining differences in long-run economic performance.

Table 2 reports the results for the estimation of the basic relation between output per worker and social infrastructure. Standard errors are computed using a bootstrap method that takes into account the fact that some of the data have been imputed. ${ }^{19}$

The main specification in Table 2 reports the results from instrumental variables estimation of the effect of a change in social infrastructure on the $\log$ of output per worker. Four instruments are used: distance from the equator, the Frankel-Romer predicted trade share, and the fractions of the population speaking English and a European language, respectively. The point estimate indicates that a difference of .01 in social infrastructure is associated with a difference in output per worker of 5.14 percent. With a

\footnotetext{
${ }^{19}$ The bootstrap proceeds as follows, with 10,000 replications. First, we draw uniformly 127 times from the set of 79 observations for which there is no missing data. Second, we create missing data. For each "country," we draw from the sample joint distribution of missing data to determine which variables, if any, are missing (any combination of GADP and years open). Third, we impute the missing data, using the method described in footnote 18. Finally, we use instrumental variables on the generated data to get a new estimate, $\bar{\beta}$. The standard errors reported in the table are calculated as the standard deviation of the 10,000 observations of $\bar{\beta}$.
} 
Table 2: Basic Results for Output per Worker

\begin{tabular}{|c|c|c|c|c|}
\hline Specification & $\begin{array}{c}\text { Social } \\
\text { Infrastructure }\end{array}$ & $\begin{array}{c}\text { OverID Test } \\
p \text {-value } \\
\text { Test Result }\end{array}$ & $\begin{array}{c}\text { Coeff Test } \\
p \text {-value } \\
\text { Test Result }\end{array}$ & $\hat{\sigma}_{\tilde{\epsilon}}$ \\
\hline 1. Main Specification & $\begin{array}{l}5.142 \\
(.508)\end{array}$ & $\begin{array}{c}.256 \\
\text { Accept }\end{array}$ & $\begin{array}{c}.812 \\
\text { Accept }\end{array}$ & .840 \\
\hline \multicolumn{5}{|c|}{ Alternative Specifications to Check Robustness } \\
\hline $\begin{array}{l}\text { 2. Instruments: } \\
\text { Distance, Frankel-Romer }\end{array}$ & $\begin{array}{l}4.998 \\
(.567)\end{array}$ & $\begin{array}{c}.208 \\
\text { Accept }\end{array}$ & $\begin{array}{c}.155 \\
\text { Accept }\end{array}$ & .821 \\
\hline $\begin{array}{l}\text { 3. No Imputed Data } \\
79 \text { Countries }\end{array}$ & $\begin{array}{l}5.323 \\
(.607)\end{array}$ & $\begin{array}{c}.243 \\
\text { Accept }\end{array}$ & $\begin{array}{c}.905 \\
\text { Accept }\end{array}$ & .889 \\
\hline 4. OLS & $\begin{array}{l}3.289 \\
(.212)\end{array}$ & - & $\begin{array}{c}.002 \\
\text { Reject }\end{array}$ & .700 \\
\hline
\end{tabular}

The coefficient on Social Infrastructure reflects the change in log output per worker associated with a one unit increase in measured social infrastructure. For example, the coefficient of 5.14 means than a difference of .01 in our measure of social infrastructure is associated with a 5.14 percent difference in output per worker. Standard errors are computed using a bootstrap method, as described in the text. The "Main Specification" uses distance from the equator, the Frankel-Romer instrument, the fraction of the population speaking English at birth, and the fraction of the population speaking a Western European language at birth as instruments. The "OverID Test" column reports the result of testing the overidentifying restrictions and the "Coeff Test" reports the result of testing for the equality of the coefficients on the GADP policy index variable and the openness variable. The standard deviation of $\log Y / L$ is 1.078 . 
standard error of .508 , this coefficient is estimated with considerable precision.

The second column of numbers in the table reports the result of testing the overidentifying restrictions of the model, such as the orthogonality of the error term and distance from the equator. These restrictions are not rejected. Similarly, we test for the equality of the coefficients on the two variables that make up our social infrastructure index, and this restriction is also not rejected.

The lower rows of the table show that our main result is robust to the use of a more limited set of instruments and to estimation using only the 79 countries for which we have a complete data set. In results not reported in the table, we have dropped one instrument at a time to ensure that no single instrument is driving the results. The smallest coefficient on social infrastructure obtained in this robustness check was 4.93.

Our estimate of $\beta$ tells us the difference in log output per worker of a difference in some exogenous variable that leads to a difference in social infrastructure. The point estimate indicates that a difference of .01 in social infrastructure, as we measure it, is associated with a difference in output per worker of a little over 5 percent. Because we believe that social infrastructure is measured with error, we need to investigate the magnitude of the errors in order to understand this number. We need to determine how much variation there is in true, as opposed to measured, social infrastructure across countries.

Our discussion starts from the premise that true simultaneity results in a positive correlation between the disturbance in our structural equation and social infrastructure. Recall that our system is:

$$
\begin{aligned}
& \log Y / L=\alpha+\beta \tilde{S}+\epsilon-\beta \nu, \\
& S=\gamma+\delta \log Y / L+X \theta+\eta
\end{aligned}
$$


The reduced-form equation for $\tilde{S}$ is

$$
\tilde{S}=\frac{\gamma+\delta \alpha+\delta \epsilon+X \theta+\eta}{1-\delta \beta}+\nu
$$

Correlation of $\tilde{S}$ with $\epsilon$ arises from two sources. One is feedback controlled by the parameter $\delta$. Provided the system satisfies the stability condition $\delta \beta<1$, a positive value of $\delta$ implies that $\epsilon$ is positively correlated with $\tilde{S}$. As we noted earlier, the natural assumption is that $\delta$ is non-negative, since social infrastructure requires some resources to build, and $\log Y / L$ measures those resources.

The second source of correlation of $\tilde{S}$ with $\epsilon$ is correlation of $\eta$ with $\epsilon$. Again, it would appear plausible that countries with social infrastructure above the level of the second structural equation would tend to be the same countries that had output per worker above the first structural equation. Thus, both sources of correlation appear to be non-negative.

On the other hand, as the reduced-form equation for $\tilde{S}$ shows, measured social infrastructure is unambiguously positively correlated with the measurement error, $\nu$. Hence there is a negative correlation between $\tilde{S}$ and the part of the disturbance in the first structural equation arising from measurement error, $-\beta \nu$.

Information about the net effect of the positive correlation arising from simultaneity and the negative correlation arising from measurement error is provided by the difference between the instrumental variables estimate of $\beta$ and the ordinary least squares estimate. The last row of Table 2 reports the latter. Because the OLS estimate is substantially smaller than the IV estimate, measurement error is the more important of the two influences.

Under the assumption that there is no true simultaneity problem, that is, $\epsilon$ is uncorrelated with $\tilde{S}$, we can calculate the standard deviation of true social infrastructure, $\sigma_{S}$, from the difference between the IV and OLS estimates. A standard result in the econometrics of measurement error is 
that OLS is biased toward zero by a multiplicative factor equal to the ratio of the variance of the true value of the right-hand variable to the variance of the measured value. Thus,

$$
\operatorname{plim}\left(\frac{\hat{\beta}_{O L S}}{\hat{\beta}_{I V}}\right)^{1 / 2}=\frac{\sigma_{S}}{\sigma_{\tilde{S}}} .
$$

That is, we can estimate the standard deviation of true social infrastructure relative to the standard deviation of measured social infrastructure as the square root of the ratio of the OLS and IV estimates. With our estimates, the ratio of the standard deviations is 0.800 .

If the correlation of $\tilde{S}$ and $\epsilon$ is positive, so true simultaneity is a problem, additional information is required to pin down $\sigma_{S}$. The positive correlation from endogeneity permits a larger negative correlation from measurement error and therefore a larger standard deviation of that measurement error. A simple calculation indicates that the ratio of standard deviations given in equation (11) is the correlation between measured and true social infrastructure, which we will denote $r_{\tilde{S}, S}$. Therefore, a lower bound on the correlation between measured and true social infrastructure provides a lower bound on $\sigma_{S}$. It is our belief, based on comparing the data in Figure 2 to our priors, that the $R^{2}$ or squared correlation between true and measured social infrastructure is no smaller than 0.5 . This implies a lower bound on $r_{\tilde{S}, S}$ of $\sqrt{.5}=.707$.

With these numbers in mind, we will consider the implications of our estimate of $\hat{\beta}_{I V}=5.14$. Measured social infrastructure ranges from a low value of 0.1127 in Zaire to a high value of 1.0000 in Switzerland. Ignoring measurement error, the implied range of variation in output per worker would be a factor of 95, which is implausibly high. We can apply the ratio $r_{\tilde{S}, S}=\sigma_{S} / \sigma_{\tilde{S}}$ to get a reasonable estimate of the range of variation of true social infrastructure. ${ }^{20}$ The lower bound on this range implied by

\footnotetext{
${ }^{20}$ That is, we calculate $\exp \left(r_{\tilde{S}, S} \hat{\beta}_{I V}\left(\tilde{S}_{\max }-\tilde{S}_{\text {min }}\right)\right)$.
} 
$r_{\tilde{S}, S}=.707$ suggests that differences in social infrastructure can account for a 25.2-fold difference in output per worker across countries. Alternatively, if there is no true endogeneity so that $r_{\tilde{S}, S}=.800$, differences in social infrastructure imply a 38.4-fold difference in output per worker across countries. For comparison, recall that output per worker in the richest country (the United States) and the poorest country (Niger) in our data set differ by a factor of 35.1.

We conclude that our results indicate that differences in social infrastructure account for much of the difference in long-run economic performance throughout the world, as measured by output per worker. Countries most influenced by Europeans in past centuries have social infrastructures conducive to high levels of output per worker, as measured by our variables, and, in fact, have high levels of output per worker. Under our identifying assumptions, this evidence means that infrastructure is a powerful causal factor promoting higher output per worker.

\subsection{Reduced-Form Results}

Table 3 reports the two reduced-form regressions corresponding to our main econometric specification. These are OLS regressions of log output per worker and social infrastructure on the four main instruments. Interpreting these regressions calls for care: our framework does not require that these reduced forms be complete in the sense that all exogenous variables are included. Rather, the equations are useful but potentially incomplete reduced-form equations.

The reduced-form equations document the close relationship between our instruments and actual social infrastructure. Distance from the equator, the Frankel-Romer predicted trade share, and the fraction of the population speaking a European language (including English) combine to explain a substantial fraction of the variance of our index of social infrastructure. 
Table 3: Reduced Form Regressions

\begin{tabular}{|c|c|c|}
\hline Regressors & $\begin{array}{l}\text { - Dependent } \\
\text { Social } \\
\text { Infrastructure }\end{array}$ & $\begin{array}{l}\text { Variables - } \\
\text { Log(Output } \\
\text { per Worker) }\end{array}$ \\
\hline $\begin{array}{l}\text { Distance from the } \\
\text { Equator, }(0,1) \text { Scale }\end{array}$ & $\begin{array}{l}0.708 \\
(.110)\end{array}$ & $\begin{array}{l}3.668 \\
(.337)\end{array}$ \\
\hline $\begin{array}{l}\text { Log of Frankel-Romer } \\
\text { Predicted Trade Share }\end{array}$ & $\begin{array}{l}0.058 \\
(.031)\end{array}$ & $\begin{array}{l}0.185 \\
(.081)\end{array}$ \\
\hline $\begin{array}{l}\text { Fraction of Population } \\
\text { Speaking English }\end{array}$ & $\begin{array}{l}0.118 \\
(.076)\end{array}$ & $\begin{array}{l}0.190 \\
(.298)\end{array}$ \\
\hline $\begin{array}{l}\text { Fraction of Population } \\
\text { Speaking a European Lang }\end{array}$ & $\begin{array}{l}0.130 \\
(.050)\end{array}$ & $\begin{array}{l}0.995 \\
(.181)\end{array}$ \\
\hline$R^{2}$ & .41 & .60 \\
\hline \multicolumn{3}{|c|}{$\begin{array}{l}\text { Note: } \mathrm{N}=127 . \text { Standard errors are computed using a bootstrap } \\
\text { method, as described in the text. A constant term is included } \\
\text { but not reported. }\end{array}$} \\
\hline
\end{tabular}

Similarly, these instruments are closely related to long-run economic performance as measured by output per worker.

\subsection{Results by Component}

Table 4 examines in more detail the sources of differences in output per worker across countries by considering why some countries have higher productivity or more physical or human capital than others.

The dependent variables in this table use the contributions to output per worker (the log of the terms in equation (3)), so that adding the coefficients across columns reproduces the coefficient in the main specification of Table 2 . Broadly speaking, the explanations are similar. Countries with a good social 
Table 4: Results for $\log K / Y, \log H / L$, and $\log A$

$$
\text { Component }=\alpha+\beta \tilde{S}+\tilde{\epsilon}
$$

\begin{tabular}{|c|c|c|c|}
\hline & \multicolumn{3}{|c|}{ Pependent Variable } \\
\hline & $\frac{\alpha}{1-\alpha} \log K / Y$ & $\log H / L$ & $\log A$ \\
\hline Social & 1.052 & 1.343 & 2.746 \\
\hline Infrastructure & $(.164)$ & $(.171)$ & $(.336)$ \\
\hline OverID Test $(p)$ & .784 & .034 & .151 \\
\hline Test Result & Accept & Reject & Accept \\
\hline$\hat{\sigma}_{\tilde{\epsilon}}$ & .310 & .243 & .596 \\
\hline$\hat{\sigma}_{D e p V a r}$ & .320 & .290 & .727 \\
\hline \multicolumn{4}{|c|}{$\begin{array}{l}\text { Note: Estimation is carried out as in the main specifi- } \\
\text { cation in Table } 2 \text {. Standard errors are computed using } \\
\text { a bootstrap method, as described in the text. }\end{array}$} \\
\hline
\end{tabular}

infrastructure have high capital intensities, high human capital per worker, and high productivity. Each of these components contributes to high output per worker.

Along with this broad similarity, some interesting differences are evident in Table 4. The residual in the equation for capital intensity is particularly large, as measured by the estimated standard deviation of the error. This leads to an interesting observation. The United States is an excellent example of a country with good social infrastructure, but its stock of physical capital per unit of output is not remarkable. While the U.S. ranks first in output per worker, second in educational attainment, and 13th in productivity, its capital-output ratio ranks 39th among the 127 countries. The U.S. ranks much higher in capital per worker (7th) because of its relatively high productivity level.

Table 5 summarizes the extent to which differences in true social infras- 
Table 5: Factors of Variation: Maximum / Minimum

\begin{tabular}{|c|c|c|c|c|}
\hline & $\bar{Y} Y / L$ & $(K / Y)^{\frac{\alpha}{1-\alpha}}$ & $\bar{H} H / L$ & $\overline{A A}$ \\
\hline $\begin{array}{l}\text { Observed Factor } \\
\text { of Variation }\end{array}$ & 35.1 & 4.5 & 3.1 & 19.9 \\
\hline $\begin{array}{l}\text { Ratio, } 5 \text { richest to } \\
5 \text { poorest countries }\end{array}$ & 31.7 & 1.8 & 2.2 & 8.3 \\
\hline $\begin{array}{l}\text { Predicted Variation, } \\
\text { Only Measurement Error }\end{array}$ & 38.4 & 2.1 & 2.6 & 7.0 \\
\hline $\begin{array}{l}\text { Predicted Variation, } \\
\text { Assuming } r_{\tilde{S}, S}^{2}=.5\end{array}$ & 25.2 & 1.9 & 2.3 & 5.6 \\
\hline \multicolumn{5}{|c|}{$\begin{array}{l}\text { The first two rows report actual factors of variation in the } \\
\text { data, first for the separate components and then for the geo- } \\
\text { metric average of the } 5 \text { richest and } 5 \text { poorest countries (sorted } \\
\text { according to } Y / L) \text {. The last two rows report predicted factors } \\
\text { of variation based on the estimated range of variation of true } \\
\text { social infrastructure. Specifically, these last two rows report } \\
\exp \left(r \hat{\beta}_{I V}\left(\tilde{S}_{\max }-\tilde{S}_{\min }\right)\right) \text {, first with } r=.800 \text { and second with } \\
r^{2}=.5 \text {. }\end{array}$} \\
\hline
\end{tabular}

tructure can explain the observed variation in output per worker and its components. The first row of the table documents the observed factor of variation between the maximum and minimum values of output per worker, capital intensity, and other variables in our data set. The second row shows numbers we have already reported in the interpretation of the productivity results. Countries are sorted by output per worker, and then the ratio of the geometric average of output per worker in the 5 richest countries to the 5 poorest countries is decomposed into the product of a capital intensity term, a human capital term, and productivity. The last two rows of the table use the basic coefficient estimates from Tables 2 and 4 to decompose the predicted factor of variation in output into its multiplicative components. 
One sees from this table that differences in social infrastructure are sufficient to account for the bulk of the observed range of variation in capital intensity, human capital per worker, and productivity. ${ }^{21}$ Interpreted through an aggregate production function, these differences are able to account for much of the variation in output per worker.

\section{Robustness of the Results}

The central equation estimated in this paper has only a single fundamental determinant of a country's output per worker, social infrastructure. Our maintained hypothesis (already tested in part using the test of overidentifying restrictions) is that this relation does not omit other fundamental determinants of output per worker. For example, characteristics of an economy such as the size of government, the rate of inflation, or the share of high-tech goods in international trade are all best thought of in our opinion as outcomes rather than determinants. Just as investment in skills, capital and technologies, these variables are determined primarily by a country's social infrastructure.

To examine the robustness of our specification, we selected a set of candidates to be additional fundamental determinants and consider a range of specifications. These alternative specifications are reported in Table 6 .

The first two specifications redefine measured social infrastructure to be either the GADP variable or the Sachs-Warner openness variable, rather than the average of the two. The results are similar to those in our main specification. When social infrastructure is measured by GADP alone, the overidentifying restrictions are rejected — some of the instruments appear to belong in the equation.

\footnotetext{
${ }^{21}$ One must be careful in interpreting these results since social infrastructure is potentially endogenous. What this statement really means is that differences in exogenous variables that lead to the observed range of variation in social infrastructure would imply the factors of variation reported in the table.
} 
Table 6: Robustness Results

$\log Y / L=\alpha+\beta \tilde{S}+\lambda$ AddedVariable $+\tilde{\epsilon}$

\begin{tabular}{|c|c|c|c|c|}
\hline Specification & $\begin{array}{c}\text { Social } \\
\text { Infrastructure } \\
\end{array}$ & $\begin{array}{l}\text { Additional } \\
\text { Variable }\end{array}$ & $\begin{array}{l}\text { OverID Test } \\
p \text {-value } \\
\text { Test Result }\end{array}$ & $\hat{\sigma}_{\tilde{\epsilon}}$ \\
\hline 1. $\tilde{S}=\mathrm{GADP}$ & $\begin{array}{l}5.410 \\
(.394)\end{array}$ & $\ldots$ & $\begin{array}{c}.006 \\
\text { Reject }\end{array}$ & .769 \\
\hline 2. $\tilde{S}=$ Years Open & $\begin{array}{l}4.442 \\
(.871)\end{array}$ & $\cdots$ & $\begin{array}{c}.131 \\
\text { Accept }\end{array}$ & 1.126 \\
\hline 3. Distance from Equator & $\begin{array}{l}5.079 \\
(2.61)\end{array}$ & $\begin{array}{c}0.062 \\
(2.062)\end{array}$ & $\begin{array}{c}.129 \\
\text { Accept }\end{array}$ & .835 \\
\hline $\begin{array}{l}\text { 4. Ethnolinguistic Fractional- } \\
\text { ization }(\mathrm{N}=113)\end{array}$ & $\begin{array}{l}5.006 \\
(.745)\end{array}$ & $\begin{array}{r}-0.223 \\
(.386)\end{array}$ & $\begin{array}{c}.212 \\
\text { Accept }\end{array}$ & .816 \\
\hline $\begin{array}{l}\text { 5. Religious Affiliation } \\
\qquad(\mathrm{N}=121)\end{array}$ & $\begin{array}{l}4.980 \\
(.670)\end{array}$ & $\begin{array}{l}\text { See } \\
\text { Note }\end{array}$ & $\begin{array}{c}.478 \\
\text { Accept }\end{array}$ & .771 \\
\hline 6. Log(Population) & $\begin{array}{l}5.173 \\
(.513)\end{array}$ & $\begin{array}{l}0.047 \\
(.060)\end{array}$ & $\begin{array}{c}.412 \\
\text { Accept }\end{array}$ & .845 \\
\hline 7. Log(C-H Density) & $\begin{array}{l}5.195 \\
(.539)\end{array}$ & $\begin{array}{l}-.546 \\
(1.11)\end{array}$ & $\begin{array}{c}.272 \\
\text { Accept }\end{array}$ & .850 \\
\hline $\begin{array}{l}\text { 8. Capitalist System } \\
\text { Indicator Variable }\end{array}$ & $\begin{array}{l}6.354 \\
(1.14)\end{array}$ & $\begin{array}{l}-1.057 \\
(.432)\end{array}$ & $\begin{array}{c}.828 \\
\text { Accept }\end{array}$ & .899 \\
\hline $\begin{array}{l}\text { 9. Instruments: Main Set plus } \\
\text { Continent Dummies }\end{array}$ & $\begin{array}{l}4.929 \\
(.388)\end{array}$ & $\cdots$ & $\begin{array}{c}.026 \\
\text { Reject }\end{array}$ & .812 \\
\hline \multicolumn{5}{|c|}{$\begin{array}{l}\text { See notes to Table } 2 . \text { Instruments are the same as in Table } 2 \text {, except where noted. } \\
\text { Additional variables are discussed in the text. The coefficients on the religious variables } \\
\text { in line } 3 \text {, followed by standard errors, are Catholic }(0.992, .354) \text {, Muslim }(0.877, .412) \text {, } \\
\text { Protestant }(0.150, .431) \text {, and Hindu }(0.839,1.48) \text {. }\end{array}$} \\
\hline
\end{tabular}


In the third specification, we treat distance from the equator as an included exogenous variable. The result, consistent with previous overidentifying tests, is little change in the coefficient on social infrastructure and a small and insignificant coefficient on distance from the equator. ${ }^{22}$ This supports our contention that the bulk of the high simple correlation between distance from the equator and economic performance occurs because historical circumstances lead this variable to proxy well for social infrastructure.

The fourth specification examines the ethnolinguistic fractionalization (ELF) index computed by Taylor and Hudson (1972) and used by Mauro (1995). ELF measures the probability that any two people chosen at random from within a country will belong to different ethnic or linguistic groups. While the simple association of this variable with output per worker is quite strong, the partial regression coefficient is small in magnitude (the variable is measured on a $[0,1]$ scale) and statistically insignificant.

The fifth specification adds religious affiliation variables to the specification. Specifically, these variables measure the fraction (on a $[0,1]$ scale) of a country's population affiliated with the Catholic, Muslim, Protestant, and Hindu religions. ${ }^{23}$ The point estimate on social infrastructure is changed little when these variables are included in the specification. Both Catholic and Muslim affiliation variables enter significantly into the regression, while the Protestant and Hindu variables do not.

The sixth specification adds the log of population to the regression. A number of recent growth models in the tradition of Romer (1990) emphasize that nonrivalry of ideas should lead to increasing returns to scale. Our

\footnotetext{
${ }^{22}$ The large standard error on social infrastructure is somewhat misleading. The associated $p$-value testing the hypothesis of a zero coefficient on social infrastructure (computed from the bootstrap distribution of coefficients) is only 0.008 . The large standard error the standard deviation of the bootstrap coefficients - occurs because the distribution of coefficients is skewed heavily toward the right, i.e. toward positive values. In contrast, the distribution of the bootstrap coefficients for distance from the equator is skewed heavily toward the left.

${ }^{23}$ These data were provided by Robert Barro and are discussed in Barro (1997).
} 
simple attempt to measure scale with population does not find evidence of this effect. One explanation is that national boundaries do not limit the areas where ideas are applied.

The seventh specification considers a measure of the density of economic activity, computed following the methods of Ciccone and Hall (1996) ${ }^{24}$ The density measure is constructed to have a theoretical coefficient of oneit would have precisely this value in Ciccone and Hall's cross section of states. Here, however, in a cross section of countries, the variation in other determinants of output per worker is so large that it is difficult to measure the effects of density with much precision.

The results for the eighth specification are unexpected. This specification adds an indicator variable taking the value of 1 for countries that are categorized as capitalist or mixed-capitalist by the Freedom House (1994). The odd result is that the regression coefficient implies that capitalist countries produce substantially less output per worker than otherwise similar noncapitalist countries. In part, this reflects the particular definition of capitalism employed by the Freedom House. According to their classification, a number of sub-Saharan African economies are classified as capitalist.

The final specification of Table 6 adds a list of continent dummies to the instrument set. ${ }^{25}$ As with the other specifications, the coefficient on social infrastructure is unchanged by the addition of the continents to the instrument list. However, the overidentification test now rejects the restric-

\footnotetext{
${ }^{24}$ The Ciccone-Hall measure for country $i$ is given by

$$
D_{i}=\frac{1}{N_{i}} \sum_{s \in S_{i}} n_{s}^{\gamma} a_{s}^{-(\gamma-1)}
$$

where $N_{i}$ is the population of country $i, S_{i}$ is the set of all provinces in country $i, n_{s}$ is the population of province $s$, and $a_{s}$ is the area of province $s$. We use a value of $\gamma=1.058$, as estimated by Ciccone and Hall. This value implies that doubling density increases $D_{i}$ by about 6 percent.

${ }^{25}$ The continents are North America (including Central America), South America, Africa, Asia (plus Oceania), and Europe.
} 
tions, in part because African economies have lower output per worker than otherwise similar economies on other continents.

\section{Conclusion}

Countries produce high levels of output per worker in the long run because they achieve high rates of investment in physical capital and human capital and because they use these inputs with a high level of productivity. Our empirical analysis suggests that success on each of these fronts is driven by social infrastructure. A country's long-run economic performance is determined primarily by the institutions and government policies that make up the economic environment within which individuals and firms make investments, create and transfer ideas, and produce goods and services.

Our major findings can be summarized by the following points:

1. Many of the predictions of growth theory can be successfully considered in a cross-section context by examining the levels of income across countries.

2. The large variation in output per worker across countries is only partially explained by differences in physical capital and educational attainment. Paralleling the growth accounting literature, levels accounting finds a large residual that varies considerably across countries.

3. Differences in social infrastructure across countries cause large differences in capital accumulation, educational attainment, and productivity, and therefore large differences in income across countries.

4. The extent to which different countries have adopted different social infrastructures is partially related to the extent to which they have been influenced by Western Europe. Using distance from the equator and language data, we conclude that our finding that differences 
in social infrastructure cause large differences in income is robust to measurement error and endogeneity concerns. 
Output per Worker Across Countries

\section{References}

Acemoglu, Daron, "Reward Structures and the Allocation of Talent," European Economic Review, January 1995, 39, 17-33.

Barro, Robert J., "Economic Growth in a Cross Section of Countries," Quarterly Journal of Economics, May 1991, 106, 407-443.

_ _ Determinants of Economic Growth: A Cross-country Empirical Study, Cambridge, MA: MIT Press, 1997.

and Jongwha Lee, "International Comparisons of Educational Attainment," Journal of Monetary Economics, December 1993, 32, 363394.

_ and Xavier Sala-i-Martin, "Convergence," Journal of Political Economy, 1992, 100 (2), 223-251.

_ _ and _ _ "Technological Diffusion, Convergence, and Growth," 1995. NBER Working Paper No. 5151.

Baumol, William J., "Entrepreneurship: Productive, Unproductive, and Destructive," Journal of Political Economy, 1990, 98 (5), 893-921. and Edward N. Wolff, "Catching up in the Postwar Period: Puerto Rico as the Fifth 'Tiger'?," World Development, 1996, 24 (5), 869-885.

Bils, Mark and Peter Klenow, "Does Schooling Cause Growth or the Other Way Around?," 1996. University of Chicago GSB mimeo.

Chari, V.V., Pat Kehoe, and Ellen McGrattan, "The Poverty of Nations: A Quantitative Investigation," 1997. Working Paper, Federal Reserve Bank of Minneapolis. 
Output per Worker Across Countries

Christensen, Laurits R., Dianne Cummings, and Dale W. Jorgenson, "Relative Productivity Levels, 1947-1973," European Economic Review, May 1981, 16 (1), 61-94.

Ciccone, Antonio and Robert E. Hall, "Productivity and the Density of Economic Activity," American Economic Review, March 1996, 86 (1), 54-70.

Coplin, William D., Michael K. O'Leary, and Tom Sealy, A Business Guide to Political Risk for International Decisions, Syracuse: Political Risk Services, 1996.

David, Paul A., "Invention and Accumulation in America's Economic Growth: A Nineteenth-Century Parable," Journal of Monetary Economics, 1977, 6 (0), 176-228. Special Supplement.

Dougherty, Chrys and Dale W. Jorgenson, "International Comparisons of the Sources of Economic Growth," American Economic Association Papers and Proceedings, May 1996, 86, 25-29.

Easterly, William, Michael Kremer, Lant Pritchett, and Lawrence Summers, "Good Policy or Good Luck? Country Growth Performance and Temporary Shocks," Journal of Monetary Economics, December 1993, 32, 459-483.

Eaton, Jonathan and Samuel S. Kortum, "Trade in Ideas: Patenting and Productivity in the OECD," 1995. NBER Working Paper No. 5049.

Engerman, Stanley L. and Kenneth L. Sokoloff, "Factor Endowments, Institutions, and Differential Paths of Growth Among New World Economies," in Stephen Haber, ed., How Latin America Fell Behind, Stanford, CA: Stanford University Press, 1997. 
Output per Worker Across Countries

Finn, James, ed., Freedom in the World: The Annual Survey of Political Rights and Civil Liberties, 1993-1994, New York: Freedom House, 1994.

Frankel, Jeffrey A. and David Romer, "Trade and Growth: An Empirical Investigation," March 1996. NBER Working Paper No. 5476.

Greif, Avner and Eugene Kandel, "Contract Enforcement Institutions: Historical Perspective and Current Status in Russia," in Edward P. Lazear, ed., Economic Transition in Eastern Europe and Russia: Realities of Reform, Stanford, CA: Hoover Institution Press, 1995, pp. 292321.

Grossman, Herschel I. and Minseong Kim, "Inequality, Predation, and Welfare," August 1996. NBER Working Paper No. 5704.

Gunnemark, Erik V., Countries, Peoples, and their Languages: The Geolinguistic Handbook, Dallas, Texas: Summer Institute of Linguistics, Inc., 1991.

Hall, Robert E. and Charles I. Jones, "The Productivity of Nations," November 1996. NBER Working Paper No. 5812.

Hunter, Barbara F., ed., Ethnologue: Languages of the World, twelth ed., Gothenburg, Sweden: Lanstryckeriet, 1992.

Islam, Nazrul, "Growth Empirics: A Panel Data Approach," Quarterly Journal of Economics, November 1995, 110, 1127-1170.

Jones, Charles I., "R\&D-Based Models of Economic Growth," Journal of Political Economy, August 1995, 103, 759-784.

Kamarck, Andrew M., The Tropics and Economic Development, Baltimore: The Johns Hopkins University Press, 1976. 
Klenow, Peter and Andres Rodriguez-Clare, "The Neoclassical Revival in Growth Economics: Has It Gone Too Far?," in Ben S. Bernanke and Julio J. Rotemberg, eds., NBER Macroeconomics Annual 1997, Cambridge, MA: MIT Press, 1997.

Knack, Stephen and Philip Keefer, "Institutions and Economic Performance: Cross-Country Tests Using Alternative Institutional Measures," Economics and Politics, November 1995, 7, 207-227.

Kornai, Janos, The Socialist System: The Political Economy of Communism, Princeton: Princeton University Press, 1992.

Krueger, Anne, "The Political Economy of the Rent-Seeking Society," American Economic Review, 1974, 64, 291-303.

Ljungqvist, Lars and Thomas J. Sargent, "The Swedish Unemployment Experience," European Economic Review, 1995, 39 (5), 10431070.

Mankiw, N. Gregory, David Romer, and David Weil, "A Contribution to the Empirics of Economic Growth," Quarterly Journal of Economics, May 1992, 107 (2), 407-438.

Mauro, Paolo, "Corruption and Growth," Quarterly Journal of Economics, August 1995, 110 (3), 681-713.

Mincer, Jacob, Schooling, Experience, and Earnings, New York: Columbia University Press, 1974.

Murphy, Kevin M., Andrei Shleifer, and Robert W. Vishny, "The Allocation of Talent: Implications for Growth," Quarterly Journal of Economics, May 1991, 106 (2), 503-530. 
Nordhaus, William D., "Climate and Economic Development," Proceedings of the World Bank Annual Conference on Development Economics 1993, 1994, pp. 355-376.

North, Douglass C., Institutions, Institutional Change, and Economic Performance, Cambridge: Cambridge University Press, 1990.

and Robert P. Thomas, The Rise of the Western World, Cambridge: Cambridge University Press, 1973.

Olson, Mancur, The Logic of Collective Action, Cambridge: Cambridge University Press, 1965.

_ _ The Rise and Decline of Nations, New Haven: Yale University Press, 1982.

Parente, Stephen L. and Edward C. Prescott, "Barriers to Technology Adoption and Development," Journal of Political Economy, April 1994, 102 (2), 298-321.

__ and __ , "Monopoly Rights: A Barrier to Riches," 1996. University of Minnesota, mimeo.

Psacharopoulos, George, "Returns to Investment in Education: A Global Update," World Development, 1994, 22 (9), 1325-1343.

Rapaczynski, Andrzej, Nature and Politics: Liberalism in the Philosophies of Hobbes, Locke, and Rousseau, Ithaca: Cornell University Press, 1987.

Romer, Paul M., "Endogenous Technological Change," Journal of Political Economy, October 1990, 98 (5), S71-S102. 
Output per Worker Across Countries

Sachs, Jeffrey D. and Andrew Warner, "Economic Reform and the Process of Global Integration," Brookings Papers on Economic Activity, 1995, 1, 1-95.

and __ , "Fundamental Sources of Long-Run Growth," American Economic Association Papers and Proceedings, May 1997, 87 (2), 184188.

Schrag, Joel and Suzanne Scotchmer, "The Self-Reinforcing Nature of Crime," 1993. Working Paper 93-11, Center for the Study of Law and Society, School of Law, University of California, Berkeley.

Solow, Robert M., "Technical Change and the Aggregate Production Function," Review of Economics and Statistics, August 1957, 39 (3), $312-320$.

Summers, Robert and Alan Heston, "The Penn World Table (Mark 5): An Expanded Set of International Comparisons: 1950-1988," Quarterly Journal of Economics, May 1991, 106, 327-368.

Taylor, Charles L. and Michael C. Hudson, World Handbook of Political and Social Indicators, New Haven: Yale University Press, 1972.

Theil, Henri and Dongling Chen, "The Equatorial Grand Canyon," De Economist, 1995, 143 (3), 317-327.

Tobler, Waldo, Uwe Deichmann, Jon Gottsegen, and Kelly Maloy, "The Global Demography Project," April 1995. NCGIA Technical Report TR-95-6, Department of Geography, U.C. Santa Barbara.

United Nations, Industrial Statistics Yearbook, 1991, Vol. 11993.

— _ National Accounts Statistics: Main Aggregates and Detailed Tables, 19921994. 
Weingast, Barry R., "The Economic Role of Political Institutions: Market-Preserving Federalism and Economic Development," Journal of Law, Economics, and Organization, April 1995, 11 (1), 1-31. 
Table 7: Productivity Calculations, Ratios to U.S. Values

\begin{tabular}{|c|c|c|c|c|c|}
\hline \multirow[b]{2}{*}{ Country } & \multirow[b]{2}{*}{ Code } & \multirow[b]{2}{*}{$Y / L$} & \multicolumn{3}{|c|}{-Contribution from- } \\
\hline & & & $(K / Y)^{\alpha /(1-\alpha)}$ & $H / L$ & $A$ \\
\hline U.S.A. & USA & 1.000 & 1.000 & 1.000 & 1.000 \\
\hline Luxembourg & LUX & 0.986 & 1.116 & 0.805 & 1.098 \\
\hline Canada & CAN & 0.941 & 1.002 & 0.908 & 1.034 \\
\hline Switzerland & $\mathrm{CHE}$ & 0.874 & 1.189 & 0.832 & 0.883 \\
\hline Australia & AUS & 0.843 & 1.094 & 0.900 & 0.856 \\
\hline Belgium & BEL & 0.836 & 1.023 & 0.836 & 0.978 \\
\hline Italy & ITA & 0.834 & 1.063 & 0.650 & 1.207 \\
\hline West Germany & DEU & 0.818 & 1.118 & 0.802 & 0.912 \\
\hline France & FRA & 0.818 & 1.091 & 0.666 & 1.126 \\
\hline Netherlands & NLD & 0.806 & 1.060 & 0.803 & 0.946 \\
\hline Sweden & SWE & 0.787 & 1.029 & 0.853 & 0.897 \\
\hline Norway & NOR & 0.759 & 1.196 & 0.909 & 0.699 \\
\hline Finland & FIN & 0.734 & 1.179 & 0.855 & 0.728 \\
\hline Iceland & ISL & 0.730 & 1.023 & 0.764 & 0.933 \\
\hline U.K. & GBR & 0.727 & 0.891 & 0.808 & 1.011 \\
\hline New Zealand & NZL & 0.717 & 1.117 & 1.017 & 0.631 \\
\hline Puerto Rico & PRI & 0.711 & 0.827 & 0.550 & 1.564 \\
\hline Austria & AUT & 0.709 & 1.076 & 0.674 & 0.979 \\
\hline Denmark & DNK & 0.690 & 1.082 & 0.905 & 0.705 \\
\hline Spain & $\mathrm{ESP}$ & 0.682 & 1.018 & 0.605 & 1.107 \\
\hline Israel & ISR & 0.659 & 0.948 & 0.851 & 0.817 \\
\hline Hong Kong & HKG & 0.608 & 0.741 & 0.735 & 1.115 \\
\hline Singapore & SGP & 0.606 & 1.031 & 0.545 & 1.078 \\
\hline Japan & JPN & 0.587 & 1.119 & 0.797 & 0.658 \\
\hline Ireland & IRL & 0.577 & 1.052 & 0.773 & 0.709 \\
\hline Saudi Arabia & SAU & 0.528 & 0.904 & 0.560 & 1.043 \\
\hline Trinidad and Tobago & TTO & 0.498 & 0.956 & 0.664 & 0.785 \\
\hline Venezuela & VEN & 0.495 & 0.994 & 0.593 & 0.839 \\
\hline Greece & GRC & 0.469 & 1.023 & 0.680 & 0.674 \\
\hline Malta & MLT & 0.463 & 0.902 & 0.692 & 0.743 \\
\hline Cyprus & CYP & 0.446 & 0.975 & 0.708 & 0.646 \\
\hline Taiwan & OAN & 0.445 & 0.821 & 0.699 & 0.776 \\
\hline Syria & SYR & 0.438 & 0.812 & 0.515 & 1.048 \\
\hline Mexico & MEX & 0.433 & 0.868 & 0.538 & 0.926 \\
\hline Oman & OMN & 0.424 & 1.132 & 0.565 & 0.663 \\
\hline Argentina & $\mathrm{ARG}$ & 0.418 & 0.953 & 0.676 & 0.648 \\
\hline U.S.S.R. & SUN & 0.417 & 1.231 & 0.724 & 0.468 \\
\hline Jordan & JOR & 0.416 & 0.783 & 0.532 & 0.998 \\
\hline Barbados & $\mathrm{BRB}$ & 0.404 & 0.728 & 0.733 & 0.756 \\
\hline Korea & KOR & 0.380 & 0.861 & 0.761 & 0.580 \\
\hline Portugal & PRT & 0.366 & 0.960 & 0.504 & 0.755 \\
\hline Uruguay & URY & 0.340 & 0.888 & 0.661 & 0.579 \\
\hline Algeria & DZA & 0.328 & 1.023 & 0.416 & 0.771 \\
\hline Brazil & BRA & 0.319 & 0.873 & 0.482 & 0.758 \\
\hline
\end{tabular}




\begin{tabular}{|c|c|c|c|c|c|}
\hline \multirow[b]{2}{*}{ Country } & \multirow[b]{2}{*}{ Code } & \multirow[b]{2}{*}{$Y / L$} & \multicolumn{3}{|c|}{ Contribution from- } \\
\hline & & & $(K / Y)^{\alpha /(1-\alpha)}$ & $H / L$ & $A$ \\
\hline Hungary & HUN & 0.307 & 1.124 & 0.932 & 0.293 \\
\hline Yugoslavia & YUG & 0.300 & 1.241 & 0.710 & 0.340 \\
\hline Iran & IRN & 0.295 & 0.981 & 0.469 & 0.642 \\
\hline Fiji & FJI & 0.273 & 0.921 & 0.682 & 0.435 \\
\hline Malaysia & MYS & 0.267 & 1.004 & 0.592 & 0.450 \\
\hline Colombia & $\mathrm{COL}$ & 0.264 & 0.818 & 0.544 & 0.593 \\
\hline Chile & CHL & 0.263 & 0.989 & 0.661 & 0.403 \\
\hline Mauritius & MUS & 0.262 & 0.614 & 0.548 & 0.778 \\
\hline Costa Rica & CRI & 0.257 & 0.862 & 0.590 & 0.506 \\
\hline Suriname & SUR & 0.254 & 0.979 & 0.400 & 0.650 \\
\hline South Africa & ZAF & 0.250 & 0.959 & 0.568 & 0.460 \\
\hline Poland & POL & 0.238 & 1.278 & 0.795 & 0.235 \\
\hline Ecuador & ECU & 0.237 & 1.012 & 0.605 & 0.386 \\
\hline Peru & PER & 0.237 & 0.935 & 0.618 & 0.409 \\
\hline Reunion & REU & 0.226 & 0.854 & 0.510 & 0.518 \\
\hline Panama & PAN & 0.223 & 1.008 & 0.651 & 0.340 \\
\hline Turkey & TUR & 0.218 & 0.925 & 0.469 & 0.503 \\
\hline Tunisia & TUN & 0.217 & 0.755 & 0.421 & 0.683 \\
\hline Seychelles & SYC & 0.215 & 0.808 & 0.407 & 0.654 \\
\hline Yemen & YEM & 0.212 & 0.617 & 0.336 & 1.022 \\
\hline Czechoslovakia & CSK & 0.211 & 1.146 & 0.763 & 0.241 \\
\hline Guatemala & GTM & 0.210 & 0.652 & 0.427 & 0.753 \\
\hline Dominican Republic & DOM & 0.206 & 0.824 & 0.525 & 0.477 \\
\hline Namibia & NAM & 0.194 & 1.255 & 0.477 & 0.324 \\
\hline Egypt & EGY & 0.187 & 0.454 & 0.576 & 0.716 \\
\hline Morocco & MAR & 0.187 & 0.618 & 0.575 & 0.527 \\
\hline Paraguay & PRY & 0.170 & 0.808 & 0.554 & 0.379 \\
\hline Swaziland & SWZ & 0.164 & 0.754 & 0.500 & 0.436 \\
\hline Gabon & GAB & 0.157 & 1.304 & 0.408 & 0.295 \\
\hline Thailand & THA & 0.157 & 0.739 & 0.575 & 0.369 \\
\hline El Salvador & SLV & 0.157 & 0.641 & 0.487 & 0.501 \\
\hline Sri Lanka & LKA & 0.155 & 0.662 & 0.593 & 0.394 \\
\hline Bolivia & BOL & 0.140 & 0.862 & 0.531 & 0.305 \\
\hline Honduras & HND & 0.130 & 0.738 & 0.486 & 0.361 \\
\hline Jamaica & JAM & 0.130 & 1.064 & 0.524 & 0.232 \\
\hline Pakistan & PAK & 0.128 & 0.582 & 0.390 & 0.566 \\
\hline Bangladesh & BGD & 0.127 & 0.384 & 0.393 & 0.844 \\
\hline Philippines & PHL & 0.126 & 0.854 & 0.663 & 0.223 \\
\hline Nicaragua & NIC & 0.126 & 0.894 & 0.501 & 0.281 \\
\hline Congo & COG & 0.122 & 0.680 & 0.460 & 0.389 \\
\hline Romania & ROM & 0.113 & 1.037 & 0.608 & 0.180 \\
\hline Indonesia & IDN & 0.110 & 0.915 & 0.499 & 0.242 \\
\hline
\end{tabular}


Output per Worker Across Countries

\begin{tabular}{|c|c|c|c|c|c|}
\hline \multirow[b]{2}{*}{ Country } & \multirow[b]{2}{*}{ Code } & \multirow[b]{2}{*}{$Y / L$} & \multicolumn{3}{|c|}{ Contribution from -} \\
\hline & & & $(K / Y)^{\alpha /(1-\alpha)}$ & $H / L$ & $A$ \\
\hline Guyana & GUY & 0.105 & 1.247 & 0.577 & 0.146 \\
\hline Ivory Coast & CIV & 0.097 & 0.739 & 0.447 & 0.294 \\
\hline Botswana & BWA & 0.094 & 1.100 & 0.496 & 0.172 \\
\hline India & IND & 0.086 & 0.709 & 0.454 & 0.267 \\
\hline Papua New Guinea & PNG & 0.078 & 0.948 & 0.377 & 0.218 \\
\hline Cameroon & CMR & 0.076 & 0.684 & 0.407 & 0.274 \\
\hline Cape Verde Island & CPV & 0.076 & 0.992 & 0.472 & 0.162 \\
\hline Senegal & SEN & 0.072 & 0.477 & 0.416 & 0.361 \\
\hline Sudan & $\mathrm{SDN}$ & 0.067 & 0.837 & 0.341 & 0.233 \\
\hline Zimbabwe & ZWE & 0.065 & 0.898 & 0.429 & 0.170 \\
\hline Sierra Leone & SLE & 0.064 & 0.291 & 0.380 & 0.581 \\
\hline Lesotho & LSO & 0.063 & 0.678 & 0.483 & 0.192 \\
\hline China & $\mathrm{CHN}$ & 0.060 & 0.891 & 0.632 & 0.106 \\
\hline Benin & $\mathrm{BEN}$ & 0.059 & 0.605 & 0.332 & 0.294 \\
\hline Haiti & HTI & 0.057 & 0.575 & 0.375 & 0.263 \\
\hline Kenya & $\mathrm{KEN}$ & 0.056 & 0.747 & 0.457 & 0.165 \\
\hline Ghana & GHA & 0.052 & 0.516 & 0.465 & 0.218 \\
\hline Zambia & ZMB & 0.051 & 1.209 & 0.535 & 0.079 \\
\hline Mauritania & MRT & 0.050 & 0.961 & 0.423 & 0.124 \\
\hline Somalia & SOM & 0.049 & 0.682 & 0.410 & 0.174 \\
\hline Gambia & GMB & 0.048 & 0.534 & 0.338 & 0.269 \\
\hline Nigeria & NGA & 0.048 & 0.937 & 0.367 & 0.140 \\
\hline Guinea & GIN & 0.043 & 0.516 & 0.414 & 0.201 \\
\hline Rwanda & RWA & 0.043 & 0.441 & 0.338 & 0.287 \\
\hline Madagascar & MDG & 0.041 & 0.299 & 0.514 & 0.264 \\
\hline Togo & TGO & 0.040 & 0.879 & 0.402 & 0.113 \\
\hline Guinea-Bissau & GNB & 0.039 & 0.859 & 0.325 & 0.140 \\
\hline Mozambique & MOZ & 0.039 & 0.349 & 0.349 & 0.321 \\
\hline Comoros & $\mathrm{COM}$ & 0.035 & 0.875 & 0.453 & 0.089 \\
\hline Mali & MLI & 0.035 & 0.524 & 0.337 & 0.196 \\
\hline Central African Rep & $\mathrm{CAF}$ & 0.033 & 0.582 & 0.357 & 0.159 \\
\hline Angola & $\mathrm{AGO}$ & 0.033 & 0.493 & 0.457 & 0.146 \\
\hline Zaire & ZAR & 0.033 & 0.499 & 0.408 & 0.160 \\
\hline Chad & TCD & 0.032 & 0.358 & 0.428 & 0.210 \\
\hline Tanzania & TZA & 0.032 & 0.650 & 0.410 & 0.119 \\
\hline Uganda & UGA & 0.032 & 0.362 & 0.390 & 0.224 \\
\hline Burundi & BDI & 0.030 & 0.495 & 0.395 & 0.152 \\
\hline Malawi & MWI & 0.030 & 0.677 & 0.427 & 0.102 \\
\hline Burkina Faso & BFA & 0.029 & 0.581 & 0.502 & 0.101 \\
\hline Myanmar & BUR & 0.029 & 0.668 & 0.396 & 0.109 \\
\hline Niger & NER & 0.029 & 0.680 & 0.325 & 0.129 \\
\hline
\end{tabular}

